\title{
Synergy between a plasminogen cascade and MMP-9 in autoimmune disease
}

\author{
Zhi Liu, ${ }^{1,2}$ Ning Li, ${ }^{1}$ Luis A. Diaz, ${ }^{1}$ J. Michael Shipley, ${ }^{3}$ Robert M. Senior, ${ }^{3}$ and Zena Werb ${ }^{4}$ \\ ${ }^{1}$ Department of Dermatology and 2Department of Microbiology and Immunology, University of North Carolina, Chapel Hill, North Carolina, USA. \\ ${ }^{3}$ Department of Medicine, Washington University School of Medicine at Barnes-Jewish Hospital, St. Louis, Missouri, USA. ${ }^{4}$ Department of Anatomy, \\ University of California, San Francisco, California, USA.
}

\begin{abstract}
Extracellular proteolysis by the plasminogen/plasmin (Plg/plasmin) system and MMPs is required for tissue injury in autoimmune and inflammatory diseases. We demonstrate that a Plg cascade synergizes with MMP-9/ gelatinase $B$ in vivo during dermal-epidermal separation in an experimental model of bullous pemphigoid (BP), an autoimmune disease. BP was induced in mice by antibodies to the hemidesmosomal antigen BP180. Mice deficient in MMP-9 were resistant to experimental BP, while mice deficient in Plg and both tissue Plg activator (tPA) and urokinase Plg activator (uPA) showed delayed and less intense blister formation induced by antibodies to BP180. Plg-deficient mice reconstituted locally with Plg or the active form of MMP-9 (actMMP-9), but not the proenzyme form of MMP-9 (proMMP-9), developed BP. In contrast, proMMP-9 or actMMP-9, but not Plg, reconstituted susceptibility of MMP-9-deficient mice to the skin disease. In addition, MMP-3-deficient mice injected with pathogenic IgG developed the same degree of BP and expressed levels of actMMP-9 in the skin similar to those of WT controls. Thus, the Plg/plasmin system is epistatic to MMP-9 activation and subsequent dermal-epidermal separation in BP.
\end{abstract}

\section{Introduction}

Extracellular proteolysis is critical for development, tissue repair, and progression of diseases in vivo (1). These processes are strictly confined because cascades of proteinases activate the zymogen forms of the proteinases. One of the best understood of these cascades is the fibrinolytic system of serine proteinases (2). The abundant zymogen plasminogen $(\mathrm{Plg})$ is proteolytically converted into the active serine proteinase plasmin by either of $2 \mathrm{Plg}$ activators, the tissue Plg activator (tPA) or the urokinase Plg activator (uPA), that then degrades fibrin. MMPs are also synthesized as zymogens that must be activated for proteolysis. The $\mathrm{Plg} / \mathrm{plasmin}$ cascade was proposed as a physiological regulatory system for activating MMPs more than 25 years ago (3). Subsequently, MMPs and serine and cysteine proteinases have been shown to activate latent forms of various members of the MMP family in vitro (4). However, little is known about the regulation of MMP activation in vivo.

Bullous pemphigoid (BP) is an autoimmune inflammatory skin disease initiated by in vivo deposition of autoantibodies and complement components at the basement membrane zone (5). BP autoantibodies recognize 2 major hemidesmosomal components, the 230-kDa intracellular protein BP230 (BPAG1) $(6,7)$ and the $180-\mathrm{kDa}$ transmembrane protein BP180 (BPAG2, or type XVII collagen) $(8,9)$. The separation of the epidermis from the dermis occurs within the lamina lucida of the basement membrane and is accompanied by an extensive inflammatory infiltrate and destruction of hemidesmosomal and extracellular matrix components (10,

Nonstandard abbreviations used: $\alpha 1$-AC, $\alpha 1$-antichymotrypsin; actMMP-9, active form of MMP-9; $\alpha 2$-AP, $\alpha 2$-antiplasmin; BP, bullous pemphigoid; i.d., intradermal(ly); mBP180, murine BP180; MC, mast cell; MPO, myeloperoxidase; NE, neutrophil elastase; PA, Plg activator; $\alpha 1$-PI, $\alpha 1$-proteinase inhibitor; Plg, plasminogen; PMN, polymorphonuclear leukocyte; proMMP-9, proenzyme form of MMP-9; tPA, tissue $\mathrm{Plg}$ activator; $\mathrm{uPA}$, urokinase $\mathrm{Plg}$ activator.

Conflict of interest: The authors have declared that no conflict of interest exists.

Citation for this article: J. Clin. Invest. 115:879-887 (2005).

doi:10.1172/JCI200523977.
11). Proteinases released from infiltrating inflammatory cells have been implicated in the subepidermal blistering of BP (12). High levels of proteolytic enzymes, including neutrophil elastase (NE), cathepsin G, Plg activators (PAs), plasmin, MMP-2/gelatinase A, and MMP-9, have been detected in BP blister fluids and lesional/ perilesional sites (13-20). NE and MMP-9 degrade the recombinant BP180 and are required for dermal-epidermal separation induced by BP autoantibodies in a skin culture model (20-22).

In the present study, we used an IgG passive transfer mouse model of BP that mimics the key features of human BP (23). In our model, subepidermal blistering triggered by anti-murine BP180 (anti-mBP180) IgG depends on complement activation, mast cell (MC) degranulation, and polymorphonuclear leukocyte (PMN) infiltration (24-26). Mice with targeted null mutations in either MMP-9 (27) or NE (28) are resistant to experimental BP. MMP-9 regulates $\mathrm{NE}$ activity by inactivating $\alpha 1$-proteinase inhibitor $(\alpha 1-P I)$, and unchecked NE degrades BP180 and other extracellular matrix components at the dermal-epidermal junction, resulting in BP lesions (29). In this report, we determine functional interactions between MMP-9 and the Plg/plasmin system in subepidermal blistering in experimental BP.

\section{Results}

Mice deficient in Plg or both $t P A$ and $u P A$ are resistant to experimental $B P$. C57BL/6J mice, tPA-deficient mice, and uPA-deficient mice ( $n=9$ for each group), injected with rabbit anti-mBP180 antibodies but not control rabbit IgG, developed typical BP skin lesions clinically and histologically 12 hours after injection (Figure 1, A, B, E, and $\mathrm{F}$; and Table 1). In contrast, mice deficient in both tPA and uPA $\left(\mathrm{tuPA}^{-/}\right)$or $\mathrm{Plg}\left(\mathrm{Plg}^{-/-}\right)$injected with the same dose of pathogenic IgG showed no skin abnormality (Figure 1, G and H). Plasmin chromogenic assays showed significantly elevated plasmin activity in the lesional skin whereas $\mathrm{Plg}^{-/-}$and $\mathrm{tuPA}^{-/}$mice exhibited only background levels of plasmin activity in the nonlesional skin (Figure 1I). As expected $(23,25)$, infiltrating neutrophils were pres- 


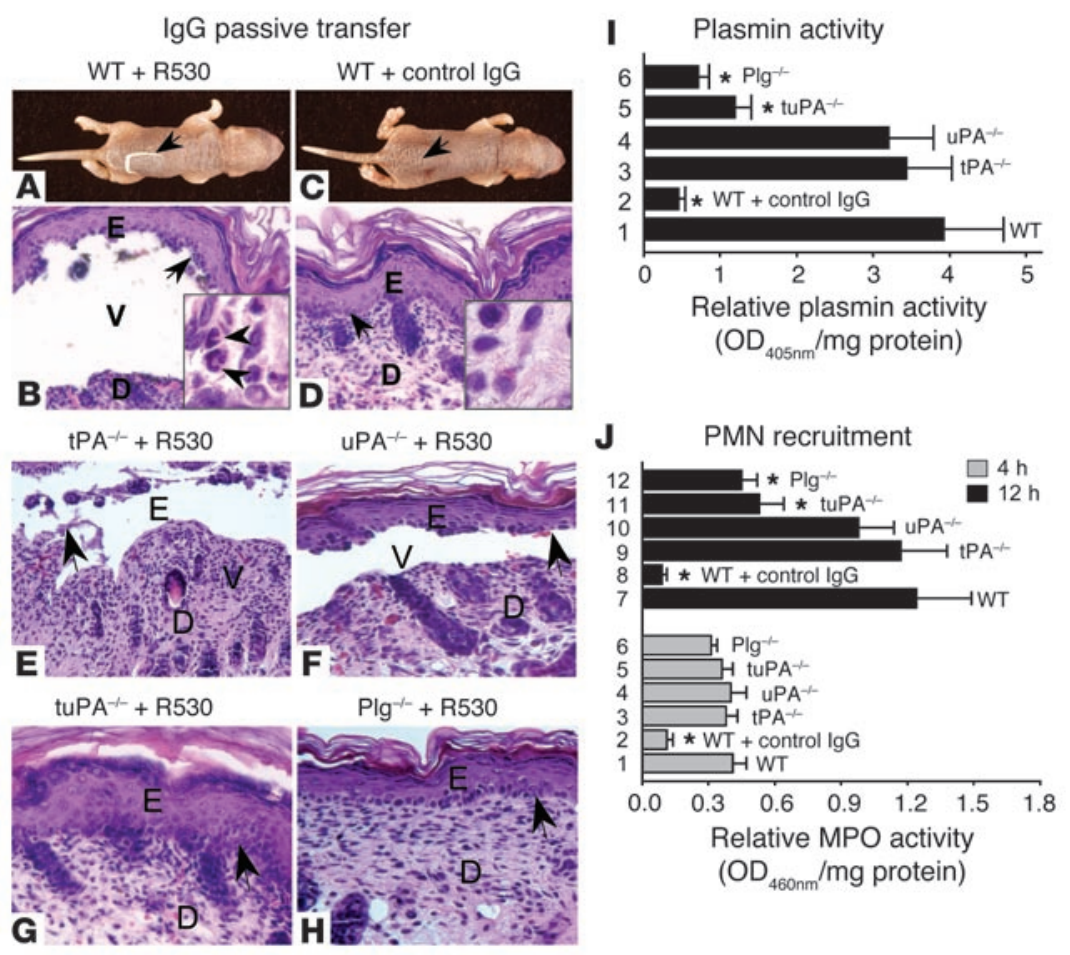

Figure 1

The PIg/plasmin system is required for experimental BP. WT mice and mice deficient in different components of the Plg/plasmin system were injected i.d. with pathogenic anti-mBP180 IgG (R530) or control IgG and examined 12 hours later. (A-H) WT (A and $\mathbf{B}), \mathrm{tPA}^{-1-}(\mathbf{E})$, and $\mathrm{UPA}^{-/-}(\mathbf{F})$, but not tuPA-1- $(\mathbf{G})$ or $\mathrm{Plg}^{-1-}(\mathbf{H})$ mice injected with pathogenic IgG developed subepidermal blisters. WT injected with control IgG showed no disease ( $\mathbf{C}$ and $\mathbf{D})$. Arrows indicate sites of basal keratinocytes. E, epidermis; D, dermis; V, blister vesicle. Magnification, $\times 200$. Higher magnifications of H\&E staining sections demonstrate infiltrating neutrophils in the dermis (insets). Arrowheads indicate neutrophils. Magnification, $\times 920$. (I) Plasmin chromogenic assay showed significantly higher levels of plasmin activity in the lesional skin of WT (bar 1), $\operatorname{tPA}^{-/-}$(bar 3), and $\mathrm{uPA}^{-/-}$(bar 4) mice as compared with the nonlesional skin of control (bar 2), tuPA-/(bar 5), and $\mathrm{Plg}^{-/}$(bar 6) mice. Data shown are the mean \pm SEM. $n=9$ for each group; ${ }^{\star} P<0.001$ versus WT. (J) MPO activity assay at 12 hours after injection (black bars) showed significantly higher levels of PMN recruitment in the lesional skin of WT (bar 7), tPA $^{-/-}$(bar 9), and uPA- ${ }^{-/}$(bar 10) mice as compared with tuPA-/- (bar 11) and $\mathrm{Plg}^{-/-}$(bar 12) mice. At 4 hours after injection (gray bars), all mice had similar numbers of infiltrating neutrophils. $n=9$ for each group; ${ }^{*} P<0.001$ versus WT.

ent in the upper dermis at the lesional/perilesional site and within the blister cavity as shown by histology (Figure 1B, inset).

At 4 hours after IgG injection, all mice had similar numbers of infiltrating neutrophils in the skin, quantified by the myeloperoxidase (MPO) assay, indicating that the absence of plasmin activity did not interfere with the early stages of neutrophil migration from the circulation into the tissue inflammatory site (Figure 1J). However, by 12 hours after injection, neutrophil infiltration was significantly higher in the diseased mice (WT, $\mathrm{tPA}^{-/-}$, and $\mathrm{uPA}^{-/-}$) than in the $\mathrm{Plg}^{-/-}$and $\mathrm{tuPA}^{-/}$unaffected mice ( $n=9$ for each group; Figure $\left.1 \mathrm{~J}\right)$. These results demonstrate that the $\mathrm{Plg} /$ plasmin system directly contributes to subepidermal blistering in experimental BP.

Plasmin acts upstream of MMP-9. Our previous data show that MMP-9 is required for subepidermal blistering (27). Since plasmin is also directly involved in disease development, we next assessed the relationship between MMP-9 and plasmin in experimental $\mathrm{BP}$ by injecting $\mathrm{Plg}^{-/-}$and MMP-9-/- mice with pathogenic anti-
mBP180 IgG, then 1 hour later reconstituting locally with Plg, the proenzyme form of MMP-9 (proMMP-9), or the active form of MMP-9 (actMMP-9) ( $n=9$ for each group). $\mathrm{Plg}^{-/}$mice reconstituted with Plg or actMMP-9, but not proMMP-9, developed BP lesions by 12 hours after IgG injection (Figure 2, A-D). MMP-9-/- mice reconstituted with actMMP-9 or proMMP-9, but not Plg, also developed subepidermal blisters (Figure 2, E-H). These results demonstrate that actMMP-9 can compensate for the deficiency of Plg in BP development while Plg cannot compensate for the deficiency of MMP-9. We conclude that plasmin acts upstream of MMP-9.

Since plasmin can activate MMP-3 and MMP-3 can activate proMMP-9 in vitro (30-33), we then sought to determine whether MMP-3 directly activates MMP-9. MMP-3 null mice $(n=8)$, when injected with pathogenic IgG, developed the same degree of BP disease as WT control mice (Table 1), and similar levels of MMP activity were found in the lesional skin of both groups of mice (Figure 2I). Furthermore, like WT mice, MMP-3 null mice $(n=8)$ pretreated with the plasmin inhibitor $\alpha 2$-antiplasmin ( $\alpha 2$-AP) became resistant to BP with minimal levels of plasmin activity in the IgG injection site (Table 1). Taken together, our data indicate that plasmin activates MMP-9 independently of MMP-3.

Lack of plasmin activity does not affect $M C$ activation. Subepidermal blistering triggered by antiBP180 antibodies depends on MC degranulation, which peaks at 2 hours after pathogenic IgG injection (26). To rule out the possibility that resistance of plasmin-deficient mice to experimental BP is due to the lack of MC activation, we quantified MC degranulation in the pathogenic IgG-injected $\mathrm{Plg}^{-/-}$and $\mathrm{tuPA}^{-/-}$mice. As shown in Figure 3, 2 hours after pathogenic IgG injection, these plasmin-deficient mice had levels of MC degranulation similar to those of WT mice and mice deficient in tPA or uPA $(n=6)$. These results demonstrate that $\mathrm{MC}$ activation is normal in plasmin activity-deficient mice and occurs upstream of plasmin generation and subsequent MMP-9 activation.

MMP-9 activation is plasmin dependent. Both proMMP-9 and actMMP-9 were present in the lesional skin of WT mice as shown by gelatin zymography (Figure 4A, lanes 1 and 3 ). In contrast, the nonlesional skin extracts of $\mathrm{Plg}^{-/-}$mice and tuPA-/- mice showed only proMMP-9 (Figure 4A, lanes 2 and 4). Plasmin converts proMMP-9 released from pathogenic anti-mBP180 IgG-stimulated neutrophils to actMMP-9 in a cell system as assayed by gelatin zymography and the MMP colorimetric assay (Figure 4B, lane 1 and bar 1). In addition, plasmin activates recombinant mouse proMMP-9 in vitro (Figure $4 \mathrm{C}$, lane 2 and bar 2). These results reveal the plasmin-dependent proteolytic activation of MMP-9 during lesion formation.

Inhibition of plasmin activity blocks blister formation in experimental $B P$. If plasmin directly contributes to MMP-9 activation, which in turn leads to subepidermal blistering in experimental BP, then blocking plasmin activity should inhibit MMP-9 activation and 


\section{Table 1}

The relationship between Plg/plasmin system and MMP-9 in experimental BP

\begin{tabular}{|c|c|c|c|}
\hline $\begin{array}{l}\text { Genotype } \\
\text { of host mice }\end{array}$ & Treatment & $\begin{array}{l}\text { No. of } \\
\text { mice }\end{array}$ & $\begin{array}{l}\text { Mean disease } \\
\text { activity score }\end{array}$ \\
\hline \multirow[t]{4}{*}{$+/+$} & - & 49 & $2.83 \pm 0.05$ \\
\hline & $+\alpha 1-A C$ & 9 & $2.78 \pm 0.12$ \\
\hline & + Active $\alpha 2-A P$ & 9 & $0.06 \pm 0.06$ \\
\hline & + Inactive $\alpha 2-A P$ & 9 & $2.78 \pm 0.12$ \\
\hline \multirow[t]{5}{*}{$\mathrm{Plg}^{-/-}$} & - & 21 & $0.00 \pm 0.00$ \\
\hline & $+\mathrm{Plg}$ & 9 & $2.78 \pm 0.15$ \\
\hline & + proMMP-9 & 9 & $0.00 \pm 0.00$ \\
\hline & + actMMP-9 & 9 & $2.72 \pm 0.15$ \\
\hline & $+5 \times 10^{5}$ PMN & 6 & $3.00 \pm 0.00$ \\
\hline $\mathrm{tPA}^{-/-}$ & - & 9 & $2.67 \pm 0.14$ \\
\hline $\mathrm{uPA}^{-/-}$ & - & 9 & $2.67 \pm 0.12$ \\
\hline tuPA ${ }^{-/-}$ & - & 9 & $0.11 \pm 0.07$ \\
\hline \multirow[t]{4}{*}{ MMP-9-/- } & - & 9 & $0.00 \pm 0.00$ \\
\hline & $+\mathrm{Plg}$ & 12 & $0.00 \pm 0.00$ \\
\hline & + proMMP-9 & 9 & $2.61 \pm 0.14$ \\
\hline & + actMMP-9 & 9 & $2.94 \pm 0.06$ \\
\hline \multirow[t]{2}{*}{ MMP-3-/- } & - & 8 & $2.81 \pm 0.09$ \\
\hline & + Active $\alpha 2-A P$ & 8 & $0.13 \pm 0.08$ \\
\hline
\end{tabular}

Neonatal $+/+, \mathrm{Plg}^{-/}, \mathrm{tPA}^{-/}, \mathrm{uPA}^{-/}, \mathrm{tuPA}^{-/-}, \mathrm{MMP}^{-9} \mathrm{9}^{-/-}$, and MMP-3-/mice were injected i.d. with pathogenic anti-mBP180 lgG $(2.64 \mathrm{mg} / \mathrm{g}$ body weight). Purified mouse Plg ( $5 \mu \mathrm{g} / \mathrm{g}$ body weight), proMMP-9 (2.5 $\mu \mathrm{g} / \mathrm{g}$ body weight), or actMMP-9 $(2.5 \mu \mathrm{g} / \mathrm{g}$ body weight) was given i.d. 1 hour after IgG injection. Purified $\alpha 1-A C(25 \mu \mathrm{g} / \mathrm{g}$ body weight), active $\alpha 2-A P(25 \mu \mathrm{g} / \mathrm{g}$ body weight), heat-inactivated $\alpha 2-\mathrm{AP}(25 \mu \mathrm{g} / \mathrm{g}$ body weight), or neutrophils $\left(5 \times 10^{5}\right.$ cells $/ 50 \mu$ in PBS) were given i.d. 90 minutes after IgG injection. Injected animals were examined clinically 12 hours after IgG injection, and disease activity was scored and averaged in each group (mean disease score \pm SEM). There was a significant difference in clinical disease scores between mice with blisters and mice without blisters $(P<0.01)$.

the disease phenotype. Accordingly, we injected neonatal WT mice with pathogenic anti-mBP180 IgG and 90 minutes later injected them at the same site with the plasmin inhibitor $\alpha 2$-AP. Control mice, which received anti-mBP180 IgG followed by PBS, developed intense blisters 12 hours after the antibody administration $(n=9$; Figure 5A). Similarly, mice coinjected with pathogenic antibody and $\alpha 1$-antichymotrypsin ( $\alpha 1$-AC) (Figure 5A), an inhibitor of the neutrophil cathepsin $\mathrm{G}$, or coinjected with pathogenic antibody plus heat-inactivated $\alpha 2$-AP also developed subepidermal blisters $(n=9$; data not shown). In contrast, mice that were treated with

\section{Figure 2}

Plasmin generation is upstream of MMP-9 activation. (A-D) actMMP-9 reconstitution restores $\mathrm{BP}$ in $\mathrm{Plg}^{-1-}$ mice. (A) Pathogenic anti-mBP180 IgG (R530, i.d. injection, $2.64 \mathrm{mg} / \mathrm{g}$ body weight) induced subepidermal blistering in neonatal $\mathrm{Plg}^{-1-}$ mice reconstituted with mouse Plg $(5 \mu \mathrm{g} / \mathrm{g}$ body weight) (B) and actMMP-9 (2.5 $\mu \mathrm{g} / \mathrm{g}$ body weight) (D) but not proMMP-9 (2.5 $\mu \mathrm{g} / \mathrm{g}$ body weight) (C) and PBS control (A). (E-H) Plg reconstitution failed to restore $\mathrm{BP}$ in $\mathrm{MMP}-9^{-/-}$mice. Pathogenic antimBP180 lgG (i.d. injection, $2.64 \mathrm{mg} / \mathrm{g}$ body weight) induced subepidermal blistering in neonatal MMP-9-/- mice reconstituted with the same amount of proMMP-9 $(\mathbf{G})$ and actMMP-9 $(\mathbf{H})$ but not mouse Plg $(\mathbf{F})$ or PBS control (E). Magnification, $\times 200$. (I) Like $+/+$ mice, MMP $-3^{-/-}$mice developed extensive clinical and histological blisters (Table 1) and compatible levels of MMP activity at 12-, 24-, 48-, and 72-hour time points as determined by MMP colorimetric assay (mean \pm SEM). pathogenic IgG followed by $\alpha 2$-AP did not develop skin lesions $(n=9$; Figure $5 \mathrm{~A})$. Blocking plasmin activity by $\alpha 2$-AP reduced $\mathrm{PMN}$ influx, which is a measure of disease severity, by $59 \%$ as determined by MPO activity (Figure 5A). Plasmin activity in the skin of mice treated with $\alpha 2$-AP was significantly inhibited compared with that in control mice or mice treated with $\alpha 1$-AC (Figure 5B). In addition, the nonlesional skin extracts of mice treated with

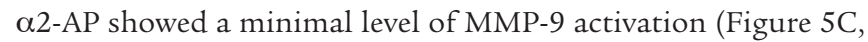
lane 2 and bar 2) while high levels of MMP-9 activation were present in the lesional skin of control mice and mice treated with $\alpha 1$-AC (Figure 5C, lanes 1 and 3, bars 1 and 3). These data further establish that MMP-9 activation in vivo depends on plasmin activity.

Local reconstitution of neutrophils restores subepidermal blistering in Plg-deficient mice. The function of actMMP-9 in experimental BP is to upregulate NE activity by inactivating $\alpha 1-\mathrm{PI}$ (29). If the major function of plasmin is to activate MMP-9, then plasmin-deficient mice should have lower levels of NE and higher levels of $\alpha 1-\mathrm{PI}$ in the pathogenic IgG-injected skin site, and local reconstitution of neutrophils should bypass the requirement of plasmin activity and restore BP disease in plasmin-deficient mice. Our next set of experiments showed that this is the case. WT, MMP-9-/-, $\mathrm{Plg}^{-/-}$, and tuPA $^{-/-}$mice ( $n=9$ for each group) were injected with pathogenic IgG. At 4 hours and 12 hours after injection, levels of plasmin, MMP-9, NE, and $\alpha 1-P I$ in the skin of these mice were quantified.
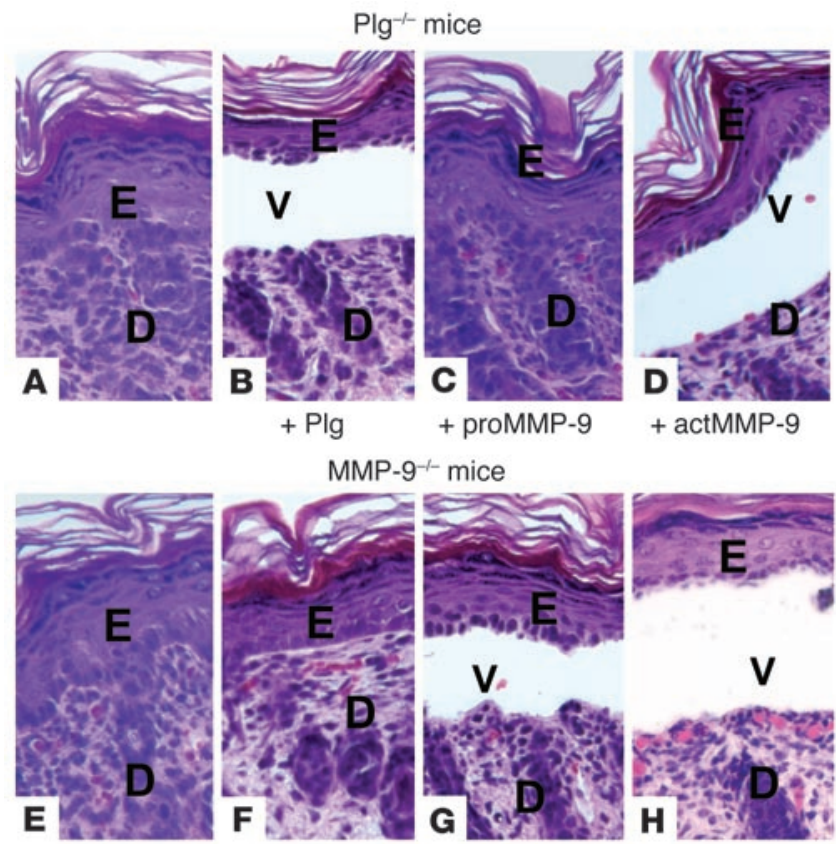

+ proMMP-9

$+\operatorname{actMMP-9}$

$$
+\mathrm{Plg}
$$
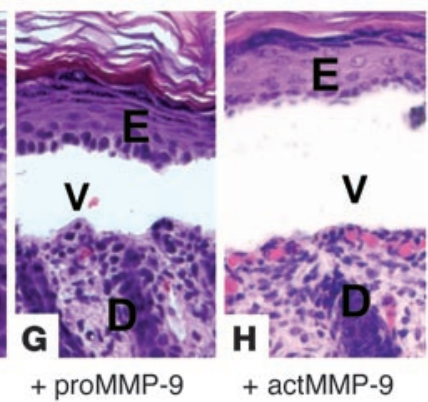

I MMP-9 activation in MMP- $3^{-1-}$ mice

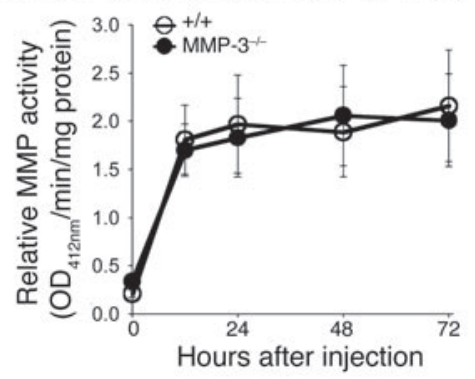


Toluidine blue staining
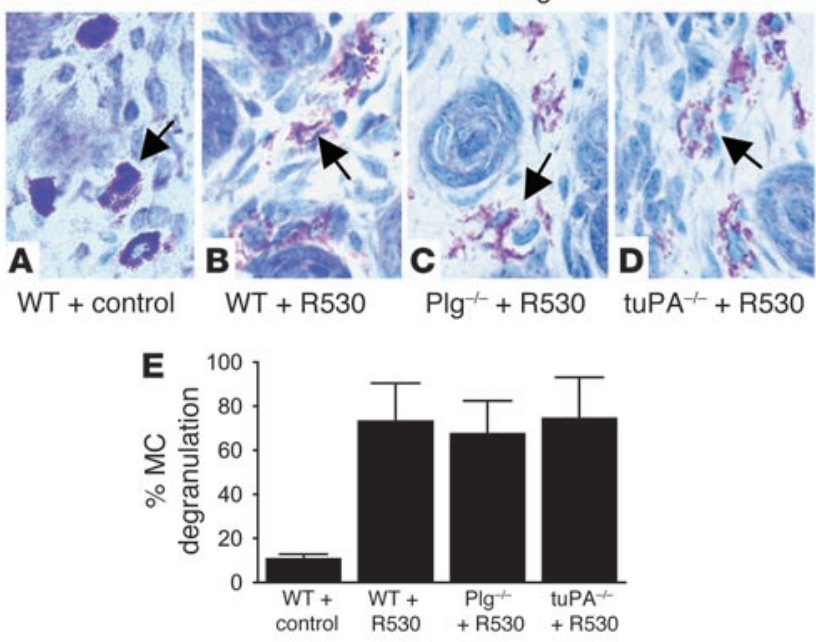

At the 4-hour time point, there was no significant difference in the levels of plasmin activity between $\mathrm{MMP}^{-9^{+/}}$and MMP-9-/- mice; their plasmin levels, however, were significantly higher than those of $\mathrm{Plg}^{-/-}$and $\mathrm{tuPA}^{-/-}$mice (Figure 6A). At the 12-hour time point, increased levels of plasmin activity were seen in the lesional skin of normal control $(+/+)$ mice as compared with the nonlesional skin of MMP-9-/-, $\mathrm{Plg}^{-/-}$, and tuPA ${ }^{--}$mice. These data reveal an amplification step for local plasmin activity during blistering, a finding similar to that observed for NE in experimental BP (29). At both 4 hours and 12 hours after injection, skin protein extracts of WT mice showed significantly higher levels of MMP activity (Figure $6 \mathrm{~B}$ ) and NE activity (Figure 6C) and lower levels of $\alpha 1$-PI activity (Figure 6D) than those of deficient mice. Levels of MMP-9, NE, and $\alpha 1-P I$ activities were compatible among these deficient mice. $\mathrm{Plg}^{-/-}$mice reconstituted with $5 \times 10^{5}$ neutrophils from $\mathrm{WT}, \mathrm{Plg}^{-/}$, or MMP-9-/- mice ( $n=6$ for each group) developed subepidermal blisters 12 hours after pathogenic IgG injection (Figure 6, E-H). These results clearly demonstrate that neutrophils are normal in $\mathrm{Plg}$ deficiency. Since local injection of $\mathrm{Plg}^{-/-}$neutrophils restored

\section{Figure 4}

MMP-9 activation by plasmin in vivo and in vitro. (A) To identify MMP-9 activation in the lesional skin of experimental $\mathrm{BP}$, neonatal $\mathrm{Plg}^{+/+}$, $\mathrm{Plg}^{-/-}, \mathrm{tuPA}^{+/+}$, and tuPA ${ }^{-/-}$mice were injected i.d. with pathogenic anti-mBP180 lgG. Skin samples were obtained at 4 hours after IgG injection, and protein extracts ( $30 \mu \mathrm{g} / \mathrm{lane}$ ) were analyzed by gelatin zymography. Both proMMP-9 and actMMP-9 were seen in lesional skin samples of IgG-injected $+/+$ mice (lanes 1 and 3 ). In contrast, no actMMP-9 was found in skin samples of pathogenic IgG-injected $\mathrm{Plg}^{-1-}$ (lane 2) and tuPA (lane 4) mice. (B) To show MMP-9 activation in a cell system, mouse neutrophils (mPMN; $\left.1 \times 10^{5}\right)$ were stimulated by pathogenic anti-mBP180 lgG (5 $\mathrm{g} / \mathrm{ml})$ plus mBP180 antigen $(5 \mu \mathrm{g} / \mathrm{ml})$ at $37^{\circ} \mathrm{C}$ for 1 hour. The supernatant was then incubated with plasmin $(2 \mu \mathrm{g} / \mathrm{ml})$ at $37^{\circ} \mathrm{C}$ for 16 hours. proMMP-9 released by neutrophils was activated by plasmin as shown by gelatin zymography (lane 1) and MMP colorimetric assay (bar 1 ). $n=6$; ${ }^{*} P<0.001$. (C) To show MMP-9 activation in vitro, the recombinant mouse proMMP-9 $(1 \mu \mathrm{g})$ was incubated with plasmin $(1 \mu \mathrm{g})$ in $100 \mu \mathrm{l}$ of reaction buffer at $37^{\circ} \mathrm{C}$ for 6 hours and assayed by gelatin zymography and MMP colorimetric assay. Plasmin converted proMMP-9 to actMMP-9 (lane 2 and bar 2), and the activation was blocked by the plasmin inhibitor $\alpha 2-\mathrm{AP}$ (lane 3 and bar 3). $n=6$; ${ }^{*} P<0.001$.

\section{Figure 3}

MC activation in Plg- and tuPA-deficient mice. WT, $\mathrm{Plg}^{-1}$, and tuPA ${ }^{-/}$ mice were injected i.d. with pathogenic IgG (R530; $2.64 \mathrm{mg} / \mathrm{g}$ body weight). At 2 hours after injection, when MC degranulation reached the peak level, skin sections were stained with toluidine blue solution. (A-D) Toluidine blue staining showed similar degrees of MC degranulation in pathogenic IgG-injected WT and deficient mice. (E) The MCs in the dermis were counted and classified as degranulated (more than $10 \%$ of the granules exhibiting fusion or discharge) or normal (see Methods). There was no significant difference in MC degranulation among these mice (mean \pm SEM). Arrows indicate MCs.

$\mathrm{BP}$ in $\mathrm{Plg}^{-/-}$mice, we conclude that the major role for plasmin is MMP-9 activation but not direct tissue injury.

To rule out the possibility that plasmin directly participates in the degradation of basement membrane proteins in the later stages during the BP blistering, we injected MMP-9-deficient mice with pathogenic IgG and examined them at 24, 48, and 72 hours after injection. All mice showed no skin lesions, which further confirms and extends our previous observations $(27,29)$.

A plasmin-independent pathway can activate MMP-9 late in the evolution of experimental BP. Our previous studies have shown that the cell population and the tissue microenvironment changes dramatically over the first 12 hours after injection of pathogenic IgG and continues to evolve over the next few days $(25,26,29)$. The experiments described above indicate that plasmin plays a critical role in MMP-9 activation during the early stages of subepidermal blistering. We then examined WT, $\mathrm{Plg}^{-/-}$, and $\mathrm{tuPA}^{-/-}$mice $(n=6)$ that were injected

A MMP-9 activation in vivo

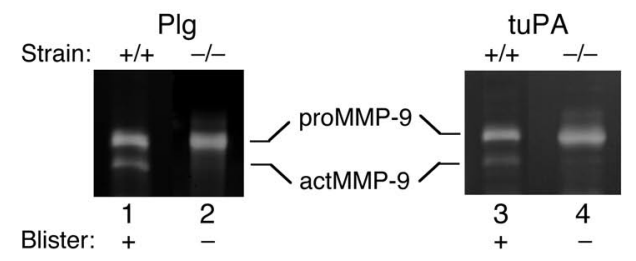

B MMP-9 activation in cell
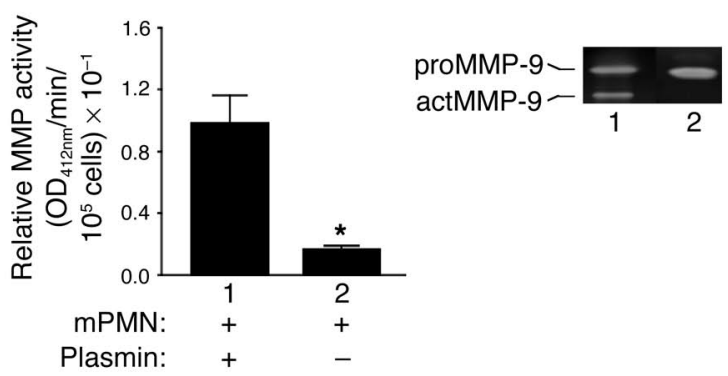

C MMP-9 activation in vitro

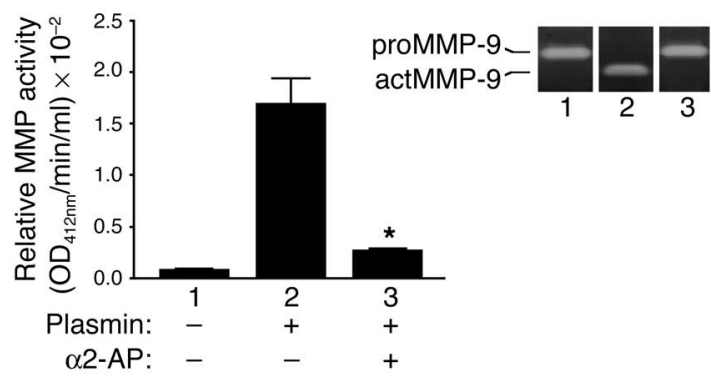



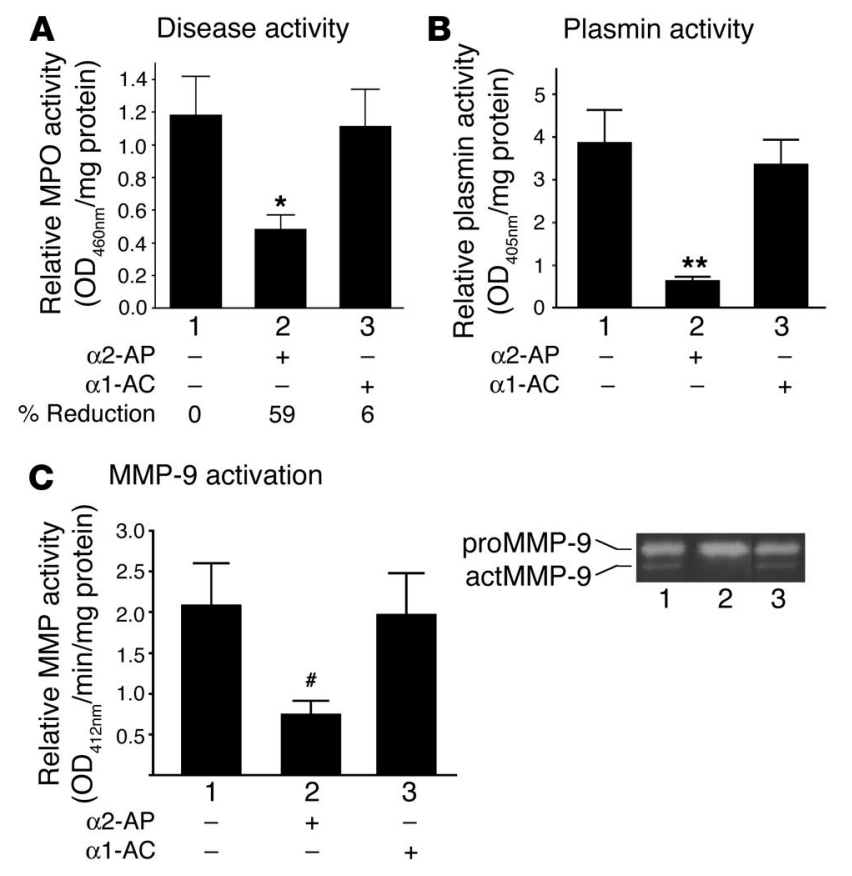

with pathogenic IgG at 12, 24, 48, and 72 hours. As expected, WT mice developed extensive BP blisters at all time points (Figure 7A). $\mathrm{Plg}^{-/-}$mice showed no skin lesions at 12 hours, but developed pathology later, showing $0.5+, 1+$ and $1.75+$ disease scores at 24 hours, 48 hours, and 72 hours, respectively. Similarly, tuPA-/- mice developed no skin blisters at 12 hours, $1+$ disease score at 24 hours, and 2+ disease score at 48 hours. We were not able to examine the later disease scores in tuPA-/- mice as all had died by 72 hours. A colorimetric assay revealed that MMP activity increased in the lesional skin of these plasmin-deficient mice after 12 hours (Figure 7B). These data suggest that in experimental BP, MMP-9 is activated initially by plasmin and later in concert with other activating enzyme(s).

\section{Discussion}

Our study shows that the $\mathrm{Plg} /$ plasmin system plays a critical role early in the evolution of subepidermal blistering in experimental $\mathrm{BP}$ by mediating the physiologic activation of MMP-9. Several lines of evidence support a role for plasmin: (a) the lesional/perilesional skin of experimental BP mice exhibited abnormally high levels of plasmin; (b) $\mathrm{Plg}^{-/-}$and tuPA-/- mice were resistant to experimental BP; (c) $\mathrm{Plg}^{-/-}$mice reconstituted with $\mathrm{Plg}$ became susceptible to experimental BP; (d) plasmin inhibitors ( $\alpha 2-\mathrm{AP})$ blocked subepidermal blistering in experimental BP; (e) in the early stages of blistering, no actMMP-9 was detected without plasmin activity, though later on, plasmin, in concert with other unidentified mechanism(s), caused MMP-9 activation and subsequent dermalepidermal separation (Figure 8).

The PA/plasmin system plays a key role in the proteolytic clearance of extracellular matrix components. Using $\mathrm{Plg}^{-/-}$mice, it has been shown that the $\mathrm{Plg} /$ plasmin cascade is directly involved in inflammation, infection, tissue injury/wound healing, cancer growth and metastasis, and antibody-mediated tissue injury (33-50). In these physiologic and pathologic conditions, the Plg/ plasmin system itself is implicated in matrix degradation. Like other MMPs, MMP-9 is secreted in an inactive form and is activated extracellularly. proMMP-9 can be activated by plasmin, uPA

\section{Figure 5}

Blocking plasmin activity abolishes experimental BP. To demonstrate that $\alpha 2-A P$ treatment blocks plasmin activity and subsequent MMP-9 activation and blistering, WT mice were injected i.d. with pathogenic anti-mBP180 lgG (2.64 mg/g body weight) followed by local administration of PBS, the plasmin inhibitor $\alpha 2-\mathrm{AP}$, or the neutrophil cathepsin $\mathrm{G}$ inhibitor $\alpha 1-\mathrm{AC}$. Mice were examined at 12 hours after IgG injection. (A) Pathogenic anti-mBP180 lgG induced high levels of neutrophil infiltration and subepidermal blisters in $+/+$ mice (bar 1) and mice treated with $\alpha 1-\mathrm{AC}$ (bar 3 ) but not in mice treated with $\alpha 2-\mathrm{AP}$ (bar 2). $n=9$; ${ }^{*} P<0.01$. (B) Plasmin activity assay showed a significant reduction of tissue plasmin activity in the $\alpha 2$-AP-treated mice (bar 2) as compared with that in the PBS-treated (bar 1) and $\alpha 1$-AC-treated mice (bar 3). $n=8$ for each group; ${ }^{\star \star} P<0.001$. (C) Zymography assay detected an actMMP-9 band in the skin of mice treated with PBS (lane 1) and $\alpha 1-A C$ (lane 3 ) but not in the skin of mice treated with $\alpha 2-A P$ (lane 2). MMP colorimetric assay revealed a significant reduction of active MMP levels in the skin samples of $\alpha 2-A P$-treated mice (bar 2) as compared with those in the lesional skin samples of PBS- (bar 1 ) and $\alpha 1$-AC-treated mice (bar 3). $n=8$; ${ }^{\#} P<0.05$.

(4, 51-54), chymase (55), tissue kallikrein (56), and other active MMPs (31, 57-60). To our surprise, we found that the major function of plasmin early in BP development is activating MMP-9, since MMP-9-/- mice reconstituted with Plg are still resistant to BP. This notion is further sustained by the striking similarity between $\mathrm{Plg}^{-/-}$and tuPA-/- mice: mice lacking Plg or PAs show very similar reduction in BP disease severity and almost identical pathology. These findings also strongly suggest that the failure to develop subepidermal blisters in $\mathrm{Plg}^{-/-}$and $\mathrm{tuPA}^{-/}$mice is due to a failure of local plasmin generation rather than some independent functional property of PA or Plg. MMP-9 can also be activated by reactive oxygen species produced by activated neutrophils (61). This pathway may play an important role in experimental BP and is currently under investigation in our laboratory.

Purified plasmin can directly activate purified mouse proMMP-9 in vitro; however, as is always the case for genetic epistasis, we cannot rule out that an intermediate enzyme is activated by plasmin and in turn activates MMP-9. It has been hypothesized that plasmin activates MMP-9 indirectly through activation of MMP-3, since in vitro plasmin activates MMP-3, which activates MMP-9, at least in human enzymes (30-33). In the present study, however, MMP-3deficient mice did not show impaired MMP-9 activation and were susceptible to experimental BP. These data exclude MMP-3 as an in vivo activator of MMP-9 in the BP model as has been reported for a vascular injury model (52).

Our experimental BP model has been very valuable in dissecting the sequence of events that lead to blister formation (29). Our present study adds a new dimension to the understanding of the early stages of disease development, showing that at 12 hours after injection, plasmin is rate limiting for MMP-9 activation and subsequent blistering. At later time points (24-72 hours), however, pathogenic IgG still induces $\mathrm{BP}$ in $\mathrm{Plg}^{-/-}$and tuPA $\mathrm{PA}^{-/}$mice, which indicates that another pathway independent of plasmin is able to overcome this defect eventually and produce the activation of MMP-9 and lesion formation. Further investigation should identify later events in the evolution of experimental BP. 

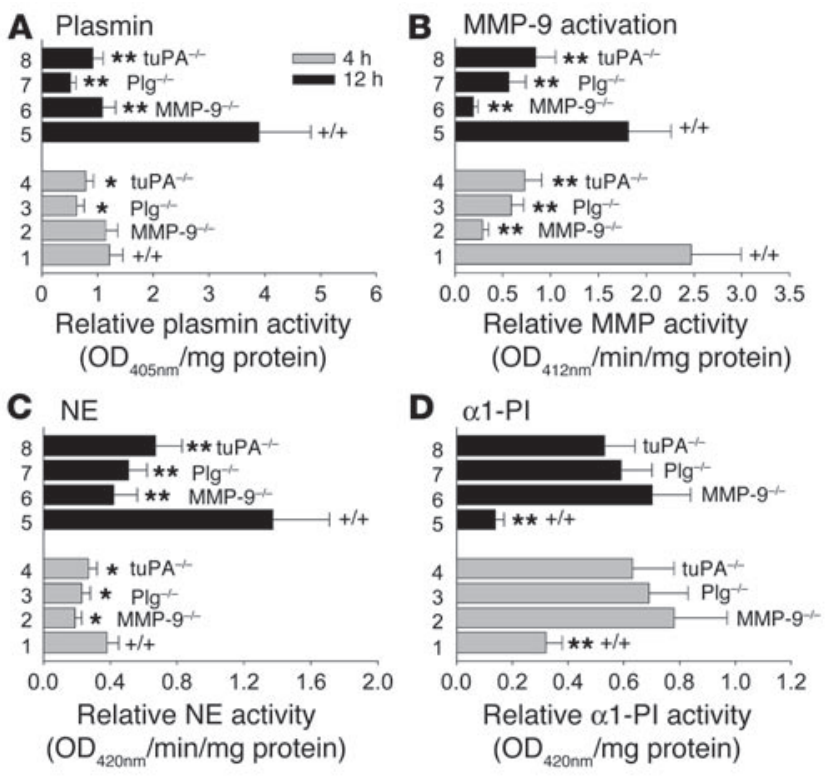

$\mathrm{PMN}$ reconstitution in $\mathrm{Plg}^{-1}$ mice
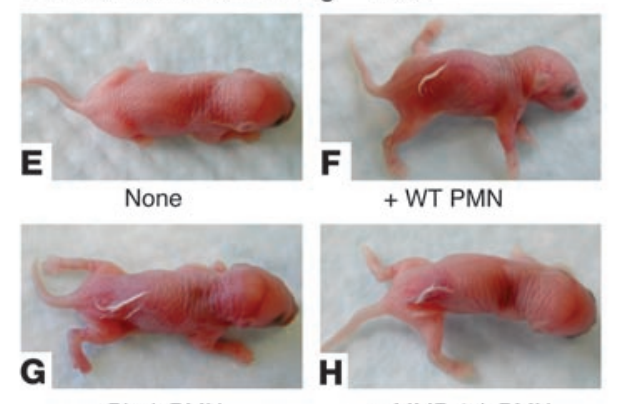

$+\mathrm{Plg}^{-1-} \mathrm{PMN}$

+ WT PMN

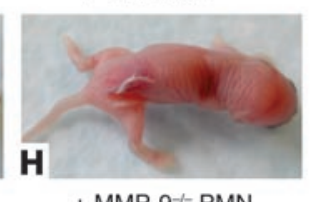

+ MMP-9-- PMN

Our current data do not rule out the possibility that plasmin also degrades basement membrane proteins, in concert with other proteolytic enzymes, after the initial tissue injury. This functional overlap between MMPs and plasmin has been observed during wound healing (62).

We have previously shown that NE and MMP-9 generate and maintain chemoattractant levels in the BP lesions in the second phase of disease development, between 6 and 12 hours after injection (27). The PA/plasmin system has also been implicated in cell migration during some physiologic and pathologic processes. However, we found no obvious impairment in recruitment of

\section{Figure 6}

Functional relationship between plasmin, MMP-9, NE, and $\alpha 1-\mathrm{PI}$ in experimental BP. +/+, MMP-9-/-, $\mathrm{Plg}^{-/}$, and tuPA ${ }^{-1-}$ mice $(n=6)$ were injected with anti-mBP180 IgG and examined 4 hours and 12 hours later. (A) Plasmin activity assay showed similar levels of tissue plasmin activity in +/+ and MMP-9-/- mice at 4 hours but significantly higher levels of tissue plasmin activity in the lesional skin of $+/+($ bar 5$)$ mice compared with MMP-9--- (bar 6), $\mathrm{Plg}^{-/}$(bar 7), and tuPA ${ }^{--}$(bar 8) mice at 12 hours. (B) MMP colorimetric assay revealed increased levels of MMP activity in lesional skin of $+/+$ mice (bars 1 and 5) as compared with those in nonlesional skin of MMP-9-/- (bars 2 and 6), $\mathrm{Plg}^{-1-}$ (bars 3 and 7), and tuPA ${ }^{--}$(bars 4 and 8 ) mice. (C) NE activity was significantly higher in the lesional skin of $+/+$ mice (bars 1 and 5 ) relative to MMP-9-/- (bars 2 and 6), $\mathrm{Plg}^{-/-}$(bars 3 and 7), and tuPA ${ }^{-/-}$(bars 4 and 8) mice. (D) NE inhibition assay showed a significantly reduced level of $\alpha 1-\mathrm{PI}$ in the lesional skin of $+/+$ mice (bars 1 and 5 ) as compared with the skin of MMP-9-/- (bars 2 and 6), $\mathrm{Plg}^{-/-}$(bars 3 and 7), and tuPA ${ }^{-/-}$ (bars 4 and 8 ) mice. ${ }^{*} P<0.05$ and ${ }^{*} P<0.001$ for paired samples. (E-H) $\mathrm{Plg}^{-1-}$ mice, when reconstituted locally with $5 \times 10^{5}$ neutrophils from $+/+(\mathbf{F}), \mathrm{Plg}^{-/-}(\mathbf{G})$, or MMP-9-/- $(\mathbf{H})$ mice, developed BP blisters 12 hours after pathogenic IgG injection. $n=6$.

neutrophils in the early stages of subepidermal blistering in mice deficient in Plg and tuPA. Initial recruitment of neutrophils at 4 hours after injection was comparable in $\mathrm{Plg}^{-1-}$, $\mathrm{tuPA}^{-1}$, and WT mice. At 12 hours after injection, when BP is fully developed, further recruitment of neutrophils is severely impaired in these deficient mice. Thus, the PA/plasmin system may contribute to neutrophil recruitment by activating MMP-9.

Does the Plg/plasmin system have any relevance to human BP? The Plg/plasmin system has been implicated in the development of BP. Elevated levels of plasmin and PAs are found in the blister fluid and lesional skin of BP patients (17-19, 63, 64).

Due to its abundance, widespread distribution, and broad substrate specificity, plasmin has been implicated in a variety of pathologies, such as thrombosis, atherosclerosis, tumor cell invasion and metastasis, and some autoimmune and inflammatory disorders (1). Although many substrates for plasmin have been identified in vitro, substrates in these pathologic conditions remain largely unknown. The present study points to MMP-9 as the critical substrate for plasmin in subepidermal blistering. Activated MMP-9 and other proteolytic enzymes damage basement membrane proteins, causing BP. Elucidation of the role of the $\mathrm{Plg} /$ plasmin system in $\mathrm{BP}$ gives us new insights into the immunopathogenesis of autoimmune diseases and suggests that this proteolytic system is a potential target for therapeutic intervention.

\section{Figure 7}

Plasmin-independent activation of MMP-9 in experimental BP. $+/+, \mathrm{Plg}^{-/}$, and tuPA ${ }^{-/}$mice $(n=6)$ were injected i.d. with pathogenic IgG $(2.64 \mathrm{mg} / \mathrm{g}$ body weight) and examined at $12,24,48$, and 72 hours after injection. Note that all tuPA ${ }^{-/}$mice died by 72 hours. (A) At 12 hours, only +/+ mice developed clinical and histological blisters. After 24 hours, all mice showed clinical blistering, but disease severity (mean disease score \pm SEM) in $\mathrm{Plg}^{-1-}$ and tuPA ${ }^{-/}$mice was significantly lower than in $+/+$mice. (B) MMP colorimetric assay showed a significantly higher MMP activity in $+/+$ mice than in $\mathrm{Plg}^{-/-}$and tuPA ${ }^{-/}$mice at all time points. ${ }^{\star} P<0.05 ;{ }^{* \star} P<0.001$.
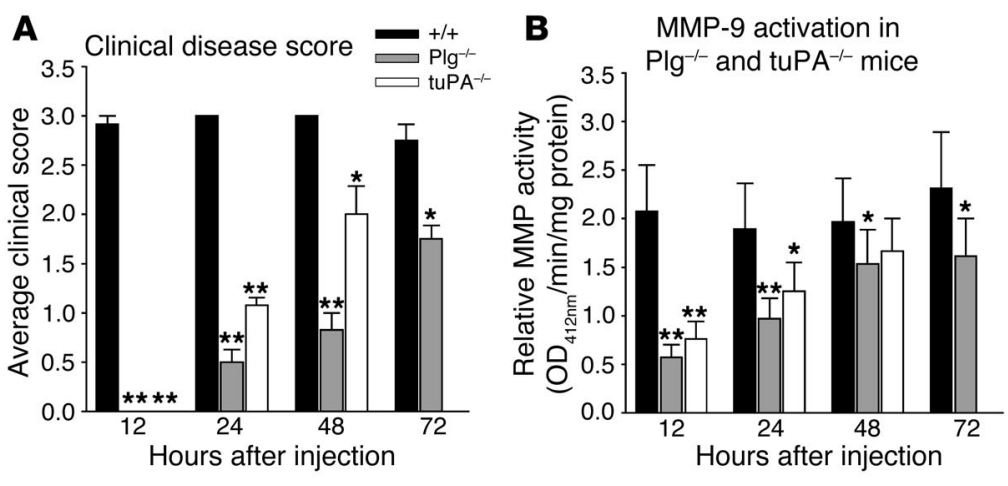


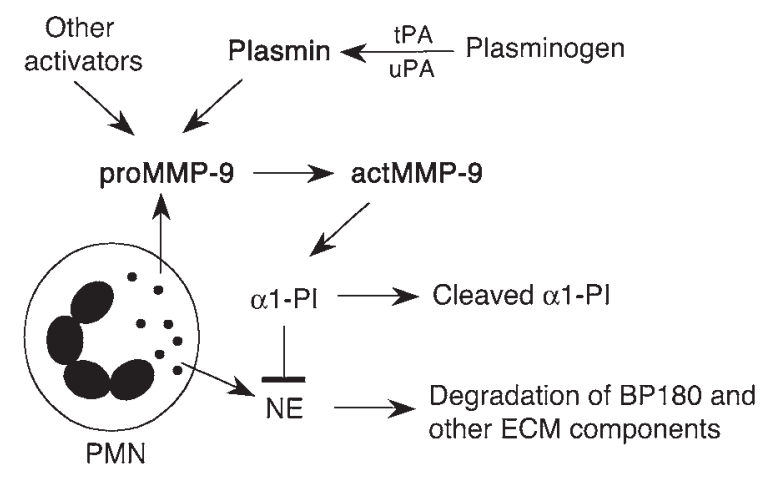

Figure 8

Working model of MMP-9 activation in experimental BP. Experimental BP is initiated by pathogenic anti-BP180 and depends on complement activation, MC degranulation, and neutrophil infiltration. Infiltrating neutrophils (PMNs) upon activation release NE, proMMP-9, and other proteinases. In the early stages of blistering, proMMP-9 is mainly activated by plasmin, which is generated from Plg by tPA and/or uPA. Plasmin and other activators of MMP-9 activate proMMP-9. actMMP-9 cleaves $\alpha 1-P I$ to release NE. Unchecked NE degrades BP180 and other ECM components, resulting in dermal-epidermal separation.

\section{Methods}

Reagents. Purified murine MMP-9 was obtained from Triple Point Biologics Inc. The proenzyme of MMP-9 was activated by incubation at $37^{\circ} \mathrm{C}$ for 4 hours with aminophenylmercuric acetate at $1 \mathrm{mM}$, and the incubation mixture was then dialyzed against $\mathrm{PBS}$ at $4^{\circ} \mathrm{C}$ to remove aminophenylmercuric acetate. Purified murine Plg was purchased from American Diagnostica Inc. Human plasmin, human $\alpha 1-A C$, human $\alpha 1$-PI, human $\alpha 2-\mathrm{AP}$, human NE, and human neutrophil MPO were from Athens Research and Technology Inc.

Animals. C57BL/6J, $\mathrm{Plg}^{-/-}, \mathrm{tPA}^{-/}$, and $\mathrm{uPA}^{-/-}$mice were purchased from the Jackson Laboratory. MMP-3 $3^{-/}$mice were obtained from Taconic. MMP-9-/- and matched normal control $(+/+)$ mice were generated as previously described (65). Mice deficient in both tPA and uPA (tuPA-/-) were generated by crossing $\mathrm{tPA}^{-/}$and $\mathrm{uPA}^{-/-}$mice followed by interbreeding of the heterozygous offspring. The identity of tuPA deficiency was confirmed by casein zymography (see below). Breeding pairs of these mice were maintained at the Medical College of Wisconsin Animal Resource Center and the Division of Laboratory Animal Medicine at the University of North Carolina at Chapel Hill. Neonatal mice, 24 to 48 hours old, weighing 1.4-2.0 g, were used for passive transfer experiments. All animal experiments were approved by the Animal Studies Committee of the University of North Carolina at Chapel Hill School of Medicine and were in accordance with NIH guidelines.

Preparation of pathogenic anti-BP180 antibodies and induction of experimental $B P$. The preparation of recombinant $\mathrm{mBP} 180$ and the immunization of rabbits were performed as previously described (23). The titers of rabbit anti-mBP180 antibodies in the rabbit sera and in the purified IgG fractions were assayed by indirect immunofluorescence, using mouse skin cryosections as substrate (23). The pathogenicity of these IgG preparations was tested by passive transfer experiments, as described below.

For induction of experimental $\mathrm{BP}$ and clinical evaluation, neonates were given 1 intradermal (i.d.) injection ( $50 \mu \mathrm{l}$ each, $2.64 \mathrm{mg} / \mathrm{g}$ body weight) of a sterile solution of IgG in PBS, as described elsewhere $(23,24)$. The skin of neonatal mice from the test and control groups was examined 12-72 hours after the IgG injections. The activity of cutaneous disease was scored as follows: 0 , no detectable skin disease; $1+$, mild erythematous reaction with no evidence of "epidermal detachment" (epidermal detachment was elicited by gentle friction of the skin which, when positive, produced fine, persistent wrinkling of the epidermis); $2+$, intense erythema and epidermal detachment involving $10-50 \%$ of the epidermis at the injection site; and $3+$, intense erythema with frank epidermal detachment involving more than $50 \%$ of the epidermis at the injection site. Disease activity in each group of mice was expressed as mean disease activity score (see Table 1).

Injection of Plg, MMP-9, $\alpha 1-A C$, and $\alpha 2-A P$. Neonatal mice were injected i.d. with $50 \mu \mathrm{l}$ of human $\alpha 1-\mathrm{AC}(25 \mu \mathrm{g} / \mathrm{g}$ body weight), human $\alpha 2-\mathrm{AP}(25$ $\mu \mathrm{g} / \mathrm{g}$ body weight), mouse Plg (5 $\mu \mathrm{g} / \mathrm{g}$ body weight), or mouse MMP-9 (2.5 $\mu \mathrm{g} / \mathrm{g}$ body weight) prior to injection of pathogenic $\operatorname{IgG}(2.64 \mathrm{mg} / \mathrm{g}$ body weight). Skin was examined at different time points for clinical lesions. IgG injection sites were excised and extracted for analysis of neutrophil infiltration and enzyme activities. Endotoxin levels in Plg, MMP-9, $\alpha 1-\mathrm{AC}$, and $\alpha 2$-AP preparations were minimal: mice injected with these reagents alone showed no inflammatory response in the skin as determined by MPO enzyme activity assay (see below).

$M P O, M M P-9$, and plasmin assays. For quantification of PMN accumulation in the skin, tissue MPO activity in skin sites of the injected animals was assayed as previously described (66), using purified MPO as standard. MPO activity in supernatants was measured by the change in OD at 460 $\mathrm{nm}$ resulting from decomposition of $\mathrm{H}_{2} \mathrm{O}_{2}$ in the presence of $o$-dianisidine. $\mathrm{MPO}$ content was expressed as relative MPO activity $\left(\mathrm{OD}_{460 \mathrm{~nm}}\right.$ reading/ $\mathrm{mg}$ protein of the mouse skin injected with pathogenic anti-mBP180 IgG minus $\mathrm{OD}_{460 \mathrm{~nm}}$ reading/mg protein of the mouse skin injected with control $\operatorname{IgG}$ ). Protein concentrations were determined by the Bio-Rad dye-binding assay (Bio-Rad Laboratories), using BSA as a standard.

MMP-9 in protein extracts of skin sections from injected animals and in supernatants of stimulated neutrophils was determined by gelatin gel zymography, as previously described $(27,67)$. Levels of active MMPs in the skin protein extracts were quantified with an MMP colorimetric assay kit following manufacturer's instructions (BIOMOL). Briefly, protein samples were incubated with the MMP colorimetric substrate Ac-PLG[2-mercapto-4-methyl]LG-OC $\mathrm{O}_{5}$ in reaction buffer (final substrate concentration, $100 \mu \mathrm{M}$ ) at $37^{\circ} \mathrm{C}$. MMP activity in protein extracts was measured by the change in $\mathrm{OD}$ at 412 $\mathrm{nm}$ and was expressed as relative MMP activity $\left(\mathrm{OD}_{412 \mathrm{~nm}}\right.$ reading/min $/ \mathrm{mg}$ protein of mouse skin injected with pathogenic IgG minus $\mathrm{OD}_{412 \mathrm{~nm}}$ reading/ $\mathrm{min} / \mathrm{mg}$ protein of mouse skin injected with normal control $\mathrm{IgG}$ ).

Plasmin activity in skin extracts of mice was measured using the chromogenic substrate Val-Leu-Lys-p-nitroanilide (Sigma-Aldrich) (68). Skin protein extracts were incubated with $0.6 \mathrm{mM}$ substrate in $50 \mathrm{mM}$ Tris- $\mathrm{HCl}, \mathrm{pH} 7.4$, and $110 \mathrm{mM} \mathrm{NaCl}$. The absorbance at $405 \mathrm{~nm}$ was read. Backgrounds due to overlapping activities of other serine proteases were determined using skin extracts plus the plasmin inhibitor $\alpha 2-\mathrm{AP}$. Plasmin activity was expressed as relative plasmin activity $\left(\mathrm{OD}_{405 \mathrm{~nm}} / \mathrm{mg}\right.$ protein minus $\mathrm{OD}_{405 \mathrm{~nm}} / \mathrm{mg}$ protein in the presence of $\left.\alpha 2-\mathrm{AP}\right)$.

Quantification of NE and $\alpha 1-P I$ activities. NE activity in the skin of mice was measured using the NE-specific substrate methoxysuccinyl-Ala-AlaPro-Val-p-nitroanalide (Met-O-Suc-Ala-Ala-Pro-Val-pNA; Enzyme Systems Products) as previously described (28). The tissue NE activity was expressed as relative $\mathrm{NE}$ activity $\left(\mathrm{OD}_{420 \mathrm{~nm}} / \mathrm{min} / \mathrm{mg}\right.$ protein). To quantify levels of $\alpha 1$-PI activity in the skin, an NE inhibition assay was employed. Briefly, purified NE was incubated with different amounts of purified $\alpha 1$-PI at $25^{\circ} \mathrm{C}$ for 5 minutes, and then the NE-specific substrate was added. Residual NE activities were measured by reading at $420 \mathrm{~nm}$ as above, and an NE-inhibition standard curve was generated. The tissue $\alpha 1-\mathrm{PI}$ activity was determined by monitoring the change in absorbance at $420 \mathrm{~nm}$ and was expressed as relative $\alpha 1$-PI activity $\left(1-\mathrm{OD}_{420 \mathrm{~nm}} / \mathrm{mg}\right.$ protein).

Isolation of PMN, local reconstitution of PMN, and activation of proMMP-9 in cell culture. PMNs were isolated from heparinized blood from WT and knockout mice by dextran sedimentation followed by separation on a density 
gradient (69). PMN purity of the final cell preparation was consistently greater than $96 \%$ as determined by cell-cytospin and LeukoStat staining (Fisher Diagnostics). The viability of the PMNs was greater than $96 \%$ as determined by trypan blue exclusion. PMNs were kept in PBS with 10 $\mathrm{mM}$ glucose at $4^{\circ} \mathrm{C}$ before use. For neutrophil reconstitution, neonatal mice were injected i.d. with pathogenic IgG and, 90 minutes later, $5 \times 10^{5}$ neutrophils in $50 \mu \mathrm{l}$ PBS were injected into the IgG-injection site. For MMP-9 activation in cell culture, $1 \times 10^{5}$ purified mouse neutrophils were activated with rabbit anti-mBP180 $\operatorname{IgG}(5 \mu \mathrm{g} / \mathrm{ml})$ and $\mathrm{mBP} 180$ antigen $(5 \mu \mathrm{g} / \mathrm{ml})$ for 1 hour at $37^{\circ} \mathrm{C}$ and then incubated with plasmin $(2 \mu \mathrm{g} / \mathrm{ml})$ at $37^{\circ} \mathrm{C}$ for 16 hours. The supernatants were collected and analyzed by gelatin zymography and the MMP-9 colorimetric assay described above.

Activation of MMP-9 by plasmin in vitro. Proteolytic activation of MMP-9 in vitro was performed as previously described (30). Briefly, $1 \mu \mathrm{g}$ of mouse MMP-9 and $1 \mu \mathrm{g}$ of human plasmin in $100 \mu \mathrm{l}$ of reaction buffer $(5 \mathrm{mM}$ Tris$\mathrm{HCl}, \mathrm{pH} 7.5$, and $0.1 \mathrm{mM} \mathrm{CaCl}_{2}$ ) were incubated at $37^{\circ} \mathrm{C}$ for 6 hours. Levels of actMMP-9 were quantified by the MMP colorimetric assay described above.

$M C$ degranulation. MCs and MC degranulation in skin samples were quantified as previously described (26). Total number of MCs was counted and classified as degranulated (more than $10 \%$ of the granules exhibiting fusion or discharge) or normal in 5 fields under a light microscope with $\times 400$ mag- nification. The results were expressed as a percentage of $\mathrm{MC}$ degranulating (number of degranulating MCs/total number of MCs per field).

Statistical analysis. For statistical analysis, the data were expressed as mean \pm SEM and were analyzed using Student's $t$ test. A $P$ value of less than 0.05 was considered significant.

\section{Acknowledgments}

We thank Sally Twining for helpful discussions, Xiaoye Zhou for excellent technical assistance, and Matthew Fleming and Simon Warren for routine histology. This work was supported in part by US Public Health Service NIH grants AI40768 and AI61430 (to Z. Liu); AR32599 and AR32081 (to L.A. Diaz); HL47328 (to R.M. Senior); and AI53194 and CA72006 (to Z. Werb).

Received for publication November 22, 2004, and accepted in revised form February 4, 2005.

Address correspondence to: Zhi Liu, Department of Dermatology, Suite 3100, Thurston Building, University of North Carolina, Chapel Hill, North Carolina 27599, USA. Phone: (919) 966-0785; Fax: (919) 966-3898; E-mail: zhiliu@med.unc.edu.
1. Werb, Z. 1997. ECM and cell surface proteolysis: regulating cellular ecology. Cell. 91:439-442.

2. Collen, D. 1999. The plasminogen (fibrinolytic) system. Thromb. Haemost. 82:259-270.

3. Werb, Z., Mainardi, C.L., Vater, C.A., and Harris, E.D., Jr. 1977. Endogenous activation of latent collagenase by rheumatoid synovial cells. Evidence for a role for plasminogen activator. N. Engl.J. Med. 296:1017-1023.

4. Woessner, J.F., and Nagase, H. 2000. Matrix metalloproteinases and TIMPs. Oxford University Press. Oxford, United Kingdom. 240 pp.

5. Stanley, J.R. 1999. Bullous pemphigoid. In Fitzpatrick's dermatology in general medicine. I.M. Freedberg et al., editors. McGraw-Hill. New York, New York, USA. 666-671.

6. Sawamura, D., Li, K., Chu, M-L., and Uitto, J. 1991. Human bullous pemphigoid antigen (BPAG1). Amino acid sequences deduced from cloned cDNAs predict biologically important peptide segments and protein domains. J. Biol. Chem. 266:17784-17790.

7. Tanaka, T., Parry, D.A.D., Klaus-Kovtun, V., Steinert, P.M., and Stanley, J.R. 1991. Comparison of molecularly cloned bullous pemphigoid antigen to desmoplakin I confirms that they define a new family of cell adhesion junction plaque proteins. J. Biol. Chem. 266:12555-12559.

8. Diaz, L.A., et al. 1990. Isolation of a human epidermal cDNA corresponding to the $180-\mathrm{kD}$ autoantigen recognized by bullous pemphigoid and herpes gestationis sera. Immunolocalization of this protein to the hemidesmosome. J. Clin. Invest. 86:1088-1094.

9. Giudice, G.J., Emery, D.E., and Diaz, L.A. 1992. Cloning and primary structural analysis of the bullous pemphigoid autoantigen, BP-180. J. Invest. Dermatol. 99:243-250.

10. Schaumburg-Lever, G., Orfanos, C.E., and Lever, C.E. 1972. Electron microscopic study of bullous pemphigoid. Arch. Dermatol. 106:662-667.

11. Dvorak, A.M., et al. 1982. Bullous pemphigoid, an ultrastructural study of the inflammatory response: eosinophil, basophil and mast cell granule changes in multiple biopsies of one patient. J. Invest. Dermatol. 78:91-101.

12. Gammon, W.R. 1989. Immune complex and complement-mediated leukocyte recruitment in bullous pemphigoid. Immunol. Ser. 46:509-525.

13. Oikarinen, A.I., Zone, J.J., Ahmed, A.R., Kiistala,
U., and Uitto, J. Demonstration of collagenase and elastase activities in blister fluids from bullous skin diseases. Comparison between dermatitis herpetiformis and bullous pemphigoid. J. Invest. Dermatol. 81:261-266.

14. Welgus, H.G., Bauer, E.A., and Stricklin, G.P. 1986. Elevated levels of human collagenase inhibitor in blister fluids of diverse etiology. J. Invest. Dermatol. 87:592-596.

15. Grando, S.A., Glukhenky, B.T., Drannik, G.N., Kostromin, A.P., and Chernyavsky, A.L. 1989. Cytotoxic proteinases in blister fluid of pemphigus and pemphigoid patients. Int. J. Tissue React. 11:195-201.

16. Grando, S.A., et al. 1989. Mediators of inflammation in blister fluids from patients with pemphigus vulgaris and bullous pemphigoid. Arch. Dermatol. 125:925-930

17. Gissler, H.M., Simon, M.M., and Kramer, M.D. 1992. Enhanced association of plasminogen/ plasmin with lesional epidermis of bullous pemphigoid. Br. J. Dermatol. 127:272-277.

18. Jensen, P.J., Baird, J., Morioka, S., Lessin, S., and Lazarus, G.S. 1988. Epidermal plasminogen activator is abnormal in cutaneous lesions. J. Invest. Dermatol. 90:777-782.

19. Kramer, M.D., and Reinartz, J. 1993. The autoimmune blistering skin disease bullous pemphigoid. The presence of plasmin/ $\alpha 2$-antiplasmin complexes in skin blister fluid indicates plasmin generation in lesional skin. J. Clin. Invest. 92:978-983.

20. Ståhle-Bäckdahl, M., Inoue, M., Giudice, G.J., and Parks, W.C. 1994. 92-kD gelatinase is produced by eosinophils at the site of blister formation in bullous pemphigoid and cleaves the extracellular domain of recombinant $180-\mathrm{kD}$ bullous pemphigoid autoantigen. J. Clin. Invest. 93:2022-2030.

21. Verraes, S., Hornebeck, W., Polette, M., Borradori, L., and Bernard, P. 2001. Respective contribution of neutrophil elastase and matrix metalloproteinase 9 in the degradation of BP180 (type XVII collagen) in human bullous pemphigoid. J. Invest. Dermatol. 117:1091-1096.

22. Shimanovich, I., et al. 2004. Granulocyte-derived elastase and gelatinase $\mathrm{B}$ are required for dermalepidermal separation induced by autoantibodies from patients with epidermolysis bullosa acquisita and bullous pemphigoid. J. Pathol. 204:519-527.

23. Liu, Z., et al. 1993. A passive transfer model of the organ-specific autoimmune disease, bullous pem- phigoid, using antibodies generated against the hemidesmosomal antigen, BP180. J. Clin. Invest. 92:2480-2488.

24. Liu, Z., et al. 1995. The role of complement in experimental bullous pemphigoid. J. Clin. Invest. 95:1539-1544.

25. Liu, Z., et al. 1997. A major role for neutrophils in experimental bullous pemphigoid. J. Clin. Invest. 100:1256-1263.

26. Chen, R., Zhou, X., Diaz, L.A., Werb, Z., and Liu, Z. 2001. Mast cells play a key role in neutrophil recruitment in experimental bullous pemphigoid. J. Clin. Invest. 108:1151-1158. doi:10.1172/ JCI200111494.

27. Liu, Z., et al. 1998. Gelatinase B-deficient mice are resistant to experimental bullous pemphigoid. J. Exp. Med. 188:475-482.

28. Liu, Z., et al. 2000. A critical role for neutrophil elastase in experimental bullous pemphigoid. J. Clin. Invest. 105:113-123.

29. Liu, Z., et al. 2000. The serpin $\alpha 1$-proteinase inhibitor is a critical substrate for gelatinase B/MMP-9 in vivo. Cell. 102:647-655.

30. Goldberg, G.I., Strongin, A., Collier, I.E., Genrich, L.T., and Marmer, B.L. 1992. Interaction of 92-kDa type IV collagenase with the tissue inhibitor of metalloproteinases prevents dimerization, complex formation with interstitial collagenase, and activation of the proenzyme with stromelysin. J. Biol. Chem. 267:4583-4591.

31. Murphy, G., Atkinson, S., Ward, R., Gavrilovic, J., and Reynolds, J.J. 1992. The role of plasminogen activators in the regulation of connective tissue metalloproteinases. Ann. N. Y. Acad. Sci. 667:1-12.

32. Ogata, Y., Enghild, J.J., and Nagase, H. 1992. Matrix metalloproteinase 3 (stromelysin) activates the precursor for the human matrix metalloproteinase 9. J. Biol. Chem. 267:3581-3584.

33. Okada, Y., et al. 1992. Matrix metalloproteinase 9 (92-kDa gelatinase/type IV collagenase) from HT 1080 human fibrosarcoma cells. Purification and activation of the precursor and enzymic properties. J. Biol. Chem. 267:21712-21719.

34. Carmeliet, P., et al. 1994. Physiological consequences of loss of plasminogen activator gene function in mice. Nature. 368:419-424.

35. Bugge, T.H., Flick, M.J., Daugherty, C.C., and Degen, J.L. 1995. Plasminogen deficiency causes severe thrombosis but is compatible with development and reproduction. Genes Dev. 9:794-807. 
36. Ploplis, V.A., French, E.L., Carmeliet, P., Collen, D., and Plow, E.F. 1998. Plasminogen deficiency differentially affects recruitment of inflammatory cell populations in mice. Blood. 91:2005-2009.

37. Goguen, J.D., Bugge, T., and Degen, J.L. 2000. Role of the pleiotropic effects of plasminogen deficiency in infection experiments with plasminogen-deficient mice. Methods. 21:179-183.

38. Romer, J., et al. 1996. Impaired wound healing in mice with a disrupted plasminogen gene. Nat. Med. 2:287-291.

39. Kao, W.W., et al. 1998. Healing of corneal epithelial defects in plasminogen- and fibrinogen-deficient mice. Invest. Ophthalmol. Vis. Sci. 39:502-508.

40. Roselli, H.T., et al. 1998. Liver regeneration is transiently impaired in urokinase-deficient mice. Am.J. Physiol. 275:G1472-G1479.

41. Bezerra, J.A., et al. 1999. Plasminogen deficiency leads to impaired remodeling after toxic injury to the liver. Proc. Natl. Acad. Sci. U. S. A. 96:15143-15148.

42. Creemers, E., et al. 2000. Disruption of plasminogen gene in mice abolishes wound healing after myocardial infarction. Am. J. Pathol. 156:1865-1873.

43. Nagai, N., De Mol, M., Lijnen, H.R., Carmeliet, P., and Collen, D. 1999. Role of plasminogen system components in focal cerebral ischemic infarction. A gene targeting and gene transfer study in mice. Circulation. 99:2440-2444.

44. Bugge, T.H., et al. 1997. Growth and dissemination of Lewis lung carcinoma in plasminogen-deficient mice. Blood. 90:4522-4531.

45. Kitching, R., et al. 1997. Plasminogen and plasminogen activators protect against renal injury in crescentic glomerulonephritis. J. Exp. Med. 185:963-968.

46. Lu, W., Bhasin, M., and Tsirka, S.E. 2002. Involvement of tissue plasminogen activator in onset and effector phases of experimental allergic encephalomyelitis. J. Neurosci. 22:10781-10789.

47. Yang, Y.H., Carmeliet, P., and Hamilton, J.A. 2001. Tissue-type plasminogen activator deficiency exacerbates arthritis. J. Immunol. 167:1047-1052.

48. Bugge, T.H., et al. 1996. Urokinase-type plasminogen activator is effective in fibrin clearance in the absence of its receptor or tissue-type plasminogen activator. Proc. Nat. Acad. Sci.U. S. A. 93:5899-5904.

49. Drew, A.F., et al. 1998. Ligneous conjunctivitis in plasminogen-deficient mice. Blood. 91:1616-1624.

50. Bezerra, J.A., et al. 2001. Plasminogen activators direct reorganization of the liver lobule after acute injury. Am.J. Pathol. 158:921-929.

51. Mazzieri, R., et al. 1997. Control of type IV collagenase activity by components of the urokinase-plasmin system: a regulatory mechanism with cell-bound reactants. EMBO J. 16:2319-2332.

52. Lijnen, H.R., et al. 1998. Function of the plasminogen/plasmin and matrix metalloproteinase systems after vascular injury in mice with targeted inactivation of fibrinolytic system genes. Arterioscler. Thromb. Vasc. Biol. 18:1035-1045.

53. Ramos-DeSimone, N., et al. 1999. Activation of matrix metalloproteinase-9 (MMP-9) via a converging plasmin/stromelysin-1 cascade enhances tumor cell invasion. J. Biol. Chem. 274:13066-13076.

54. Davis, G.E., Pintar Allen, K.A., Salazar, R., and Maxwell, S.A. 2001. Matrix metalloproteinase-1 and -9 activation by plasmin regulates a novel endothelial cell-mediated mechanism of collagen gel contraction and capillary tube regression in three-dimensional collagen matrices. J. Cell Sci. 114:917-930.

55. Fang, K.C., Raymond, W.W., Blount, J.L., and Caughey, G.H. 1997. Dog mast cell alpha-chymase activates progelatinase B by cleaving the Phe88Gln89 and Phe91-Glu92 bonds of the catalytic domain. J. Biol. Chem. 272:25628-25635.

56. Desrivieres, S., et al. 1993. Activation of the 92 $\mathrm{kDa}$ type IV collagenase by tissue kallikrein. J. Cell. Physiol. 157:587-593.

57. Fridman, R., Toth, M., Pena, D., and Mobashery, S. 1995. Activation of progelatinase B (MMP-9) by gelatinase A (MMP-2). Cancer Res. 55:2548-2555.

58. Imai, K., et al. 1995. Matrix metalloproteinase 7 (matrilysin) from human rectal carcinoma cells. Activation of the precursor, interaction with other matrix metalloproteinases and enzymic properties. J. Biol. Chem. 270:6691-6697.

59. Knauper, V., Smith, B., Lopez-Otin, C., and Murphy, G. 1997. Activation of progelatinase B (proMMP-9) by active collagenase-3 (MMP-13). Eur. J. Biochem. 248:369-373.

60. von Bredow, D.C., Cress, A.E., Howard, E.W., Bowden, G.T., and Nagle, R.B. 1998. Activation of gelatinase-tissue-inhibitors-of-metalloproteinase complexes by matrilysin. Biochem. J. 331:965-972.

61. Peppin, G.J., and Weiss, S.J. 1986. Activation of the endogenous metalloproteinase, gelatinase, by triggered human neutrophils. Proc. Natl.Acad.Sci.U.S.A. 83:4322-4326.

62. Lund, L.R., et al. 1999. Functional overlap between two classes of matrix-degrading proteases in wound healing. EMBO J. 18:4645-4656.

63. Baird, J., et al. 1990. mRNA for tissue-type plasminogen activator is present in lesional epidermis from patients with psoriasis, pemphigus, or bullous pemphigoid, but is not detected in normal epidermis. J. Invest. Dermatol. 95:548-552.

64. Venning, V.A., Wojnarowska, F., and CederholmWilliams, S. 1993. An immunohistochemical study of the distribution of plasminogen and plasminogen activators in bullous pemphigoid. Clin. Exp. Dermatol. 18:119-123.

65. Vu, T.H., et al. 1998. MMP-9/gelatinase B is a key regulator of growth plate angiogenesis and apoptosis of hypertrophic chondrocytes. Cell. 93:411-422.

66. Bradley, P.P., Priebat, D.A., Christensen, R.D., and Rothstein, G. 1982. Measurement of cutaneous inflammation: estimation of neutrophil content with an enzyme marker. J. Invest. Dermatol. 78:206-209.

67. Twining, S.S., et al. 1997. Changes in rat corneal matrix metalloproteinases and serine proteinases under vitamin A deficiency. Curr. Eye Res. 16:158-165.

68. Friberger, P. 1982. Chromogenic peptide substrates. Their use for the assay of factors in the fibrinolytic and the plasma kallikrein-kinin systems. Scand. J. Clin. Lab. Invest. 162(Suppl.):1-298.

69. Clark, R.A., and Nauseef, W.M. 1994. PMN isolation. In Current protocols in immunology. J.E. Coligan, A.M. Kruisbeek, D.H. Margulies, E.M. Shevach, and W. Strober, editors. John Wiley \& Sons, Inc. New York, New York, USA. 7.23.1-7.23.17. 